\title{
Model For Development Of Students 'Capability In Industry Practices In Era 4.0
}

\author{
Yoto, Marsono $^{1}$, Bella Cornelia Tjiptady ${ }^{2}$ \\ ${ }^{1}$ Program Studi Pendidikan Teknik Mesin \\ ${ }^{2}$ Fakultas Teknik Universitas Negeri Malang \\ Jl. Semarang No. 5 Malang \\ Email: ${ }^{1}$ yoto.ft@um.ac.id
}

\begin{abstract}
Vocational education in the industrial revolution era 4.0 needs to get support from various parties in order to have a major contribution in economic development. The problem faced at this time is the weak ability of human resources, especially in creativity and innovation capability. One solution that can be done by vocational education is the presence of industrial practices. This paper presents a model for developing learners' capabilities through industrial practices that begin with planning from preparation, implementation, and evaluation. The purpose of this paper is to describe the implementation of industrial practice models. Through this model, institutions can use them to improve the capabilities of program students in the 4.0 era.
\end{abstract}

Keywords: Industrial practice models, capabilities, 4.0 era

\section{Introduction}

According to Schaap, Baartman, and Bruijn (2012) vocational education in Indonesia aims to develop competencies so that each student can be absorbed in the world of work. Baartman and Bruijn (2011) state that the steps that can be taken to create a professional workforce are by creating vocational graduates who are in accordance with their field skills, have a professional attitude, and high self-confidence. Based on the reality, the ability possessed by vocational education graduates, namely SMKs, still does not meet the qualification standards required by the workforce (Polat, Uzmanoğlu, İşgören, Çınar, Tektaş, Oral, and Öznaz, 2010). This happens because the competency of SMK graduates is still low so there are still SMK graduates who do not get a job (Wibowo, 2016).

According to Oesterreich \& Teuteberg (2016) the globalization system in the 4.0 era demanded that people always be alert to the conditions that occur. Basically, every time there can be a change in life patterns so that students who are not ready will surely be consumed by the wheel of life. Enke, Glass, Kreß, Hambach, Tisch, \& Metternich (2018) state that the development of science and technology has brought enormous changes in the world of education. Weak ability of students to develop the capabilities of innovation and creativity will have an impact on the weak competitive advantage and business performance as well. The lack of innovation capability and a good work ethic will have an impact on a country's backwardness in the economic development and welfare of its people (Ndubisi, Dayan, Yeniaras, \& Alhawari, 2019). So that macro can threaten the economic stability of the community. What can threaten the economic stability of the community besides that is the industry 4.0, SMKs must strive to innovate and create to respond to changes, challenges, and opportunities of the industrial era 4.0 so as not to further contribute to the unemployment rate in Indonesia. Bearing in mind, the current objective of holding vocational education is still far from ideal, as stated in the objective of establishing a vocational school.

Rossini, Costa, Staudacher, \& Tortorella, (2019) stated that the phases of the industrial revolution 4.0 had an impact on changes in human activity in the scale, scope, complexity, and transformation of previous life experiences. Every student 
will begin to be replaced by industrial automation. Therefore every student must have the capability to be able to predict market demand and a dynamic future. Not only students, but the country must also respond to these changes in an integrated and comprehensive manner. The response involved all global political stakeholders, ranging from the public, private, academic, and civil society sectors so that challenges in the industrial era 4.0 could be managed as opportunities. These challenges must be answered quickly and appropriately by the Indonesian government, one of which can be pursued through industry practice. Industrial practice is one of the programs carried out by schools that work closely with the industrial world in achieving professional expertise for vocational school graduates.

Competencies that must be possessed by vocational graduates should be in accordance with the objectives of the provision of vocational education, namely to prepare mid-level skilled workers in certain areas of expertise in accordance with the needs in the industry. This is made clear by a study conducted by Carli, Suherman, \& Sumarna (2016), that the standard competency of SMK / MAK graduates is to master the competency of the expertise program, both to meet the demands of the workforce and to attend higher education in accordance with their vocational training. In line with Kennedy (2011), vocational education is also directed to increase individual independence in developing students' capabilities in accordance with their expertise program.

The development of students' capabilities in vocational education must be pursued immediately in order to increase innovation and creation so that the goals of vocational education especially vocational schools can be realized and graduates are able to synergize with the demands of the times. The effort that needs to be realized is to do the relevance of SMK and work to respond to changes, challenges, and opportunities in the industrial era 4.0 while keeping humanity in mind.

Following up on challenges in developing student capabilities, Bukit (2014) explained that vocational education as an education that is different from other types of education so that it must have the following characteristics: (1) oriented towards individual performance in the world of work; (2) specific justifications for real needs on the ground; (3) curriculum focus on psychomotor, affective, and cognitive aspects; (4) benchmarks for success are not limited to school; (5) sensitivity to the development of the world of work; 6) require adequate facilities and infrastructure; and (7) community support. Based on the explanation above, vocational education in this case SMK is a unique type of education because it aims to develop capabilities of understanding, attitudes, and work habits that are useful for individuals so that they can meet social, political, and economic needs in accordance with their characteristics. Vocational education and training is an educational approach that emphasizes the needs of the industry so that individual improvement and development can be carried out in the industry (Zaib \& Harun, 2014). Starting from the theory put forward, vocational high schools (SMK) have the opportunity to answer challenges in the industrial era 4.0.

The embodiment of the SMK follow-up to industry challenges 4.0 is the realization of vocational education by carrying out a revitalization that includes all components of learning in SMK. The revitalization includes a learning system including; (1) curriculum and character education; (2) learning materials based on information and communication technology; entrepreneurship; (4) alignment; and (5) evaluation. Educational unit includes; (1) new school units and new classrooms; (2) other study rooms; (3) classroom rehabilitation; (4) student and teacher dormitories; (5) equipment; and (6) school management and culture. Elements of students include; (1) scholarships; and (2) 
talent development of interest. Elements of educators and education personnel include; (1) provision; (2) distribution; (3) qualifications; (4) certification; (5) training; (6) career and welfare; and (7) respect and protection.

Learning content in the 4.0 era must always be sensitive to the dynamism of the times. The content of learning is expected to fulfill 21st century skills including: (1) learning and innovation skills including the acquisition of diverse knowledge and skills, learning and innovation, critical thinking and problem solving, communication and collaboration, and creativity and innovation; (2) digital literacy skills include information literacy, media literacy, and ICT literacy; and (3) career and life skills including flexibility and adaptability, initiative, social and cultural interaction, productivity and accountability, and leadership and responsibility (Trilling \& Fadel, 2009).

The 4th industrial revolution began in Germany in 1990-2000 and spread rapidly to the US and other developed countries. The fourth industrial revolution (industry 4.0), among others, marked the emergence of the internet (cyber), supercomputers, smart robots, micro chips, genetic editing, and neurotechnology that enable humans to further optimize brain function (Schwab, 2016). One of the unique characteristics of Industry 4.0 is the application of artificial intelligence (Tjandrawinata, 2016). Where one form of implementation is the use of robots to replace the human tenga so that it is cheaper, effective, and efficient. The implication, will change the pattern of life and human interaction, because fundamentally there has been a technological change with a new approach that combines the physical world, digital, and biology.

Lee, Lapira, Bagheri, \& Kao (2013) explained that industry 4.0 was marked by an increase in digitalization which was driven by four factors, including: (1) an increase in data volume, computational power, and connectivity; (2) emergence of business analysis, skills and intelligence; (3) new forms of interaction between humans and machines; and (4) improvement of digital transfer instructions to the physical world, such as robotics and 3D printing. This was also added by Lifter and Tscheiner (2013), the basic principle of Industry 4.0 is the integration of machines, workflows and systems by implementing intelligent networks along the production chain and processes to control each other independently.

In relation to the basic principles above, industry 4.0 has introduced flexible mass technology (Kagermann, Wahlster, \& Helbig, 2013). The technology has been integrated with machines that will operate independently or coordinate with humans (Sung, 2017). Industry 4.0 is an approach to control the production process by synchronizing the time when production unification and adjustment occur (Kohler \& Wisz, 2016). Furthermore, Zesulka, Marcon, Vesely, \& Sajdl (2016) added, industry 4.0 was used on three interrelated factors, namely: (1) digitization and economic interaction with simple techniques towards economic networks with complex techniques; (2) digitization of products and services; and (3) new market models. In line with this, Baur and Wee (2015) map industry 4.0 with the term "digital compass" as follows. 


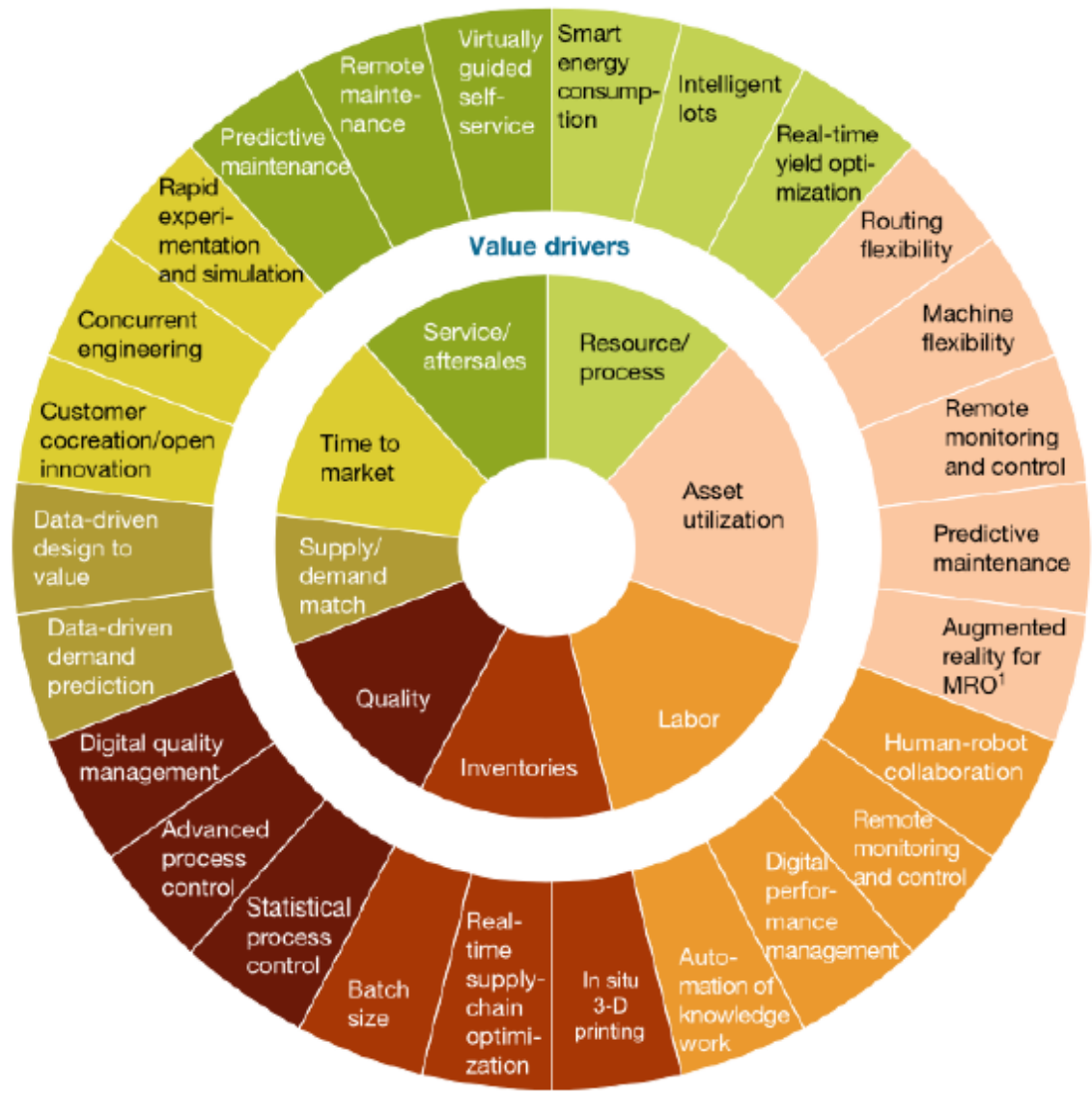

Figure 1. Industry level 4.0

(Source: Baur \& Wee, 2015)

Figure 1 is an instrument for companies in implementing Industry 4.0 to suit their needs. In figure 1 , the labor component must fulfill: (1) human collaboration with robots; (2) remote control and control; (3) digital performance management; and (4) work knowledge automation. Likewise, other components are used as instruments for industry 4.0 implementation.

Industry 4.0 is also referred to as a technological revolution because there has been a technological disruption where automation and connectivity have occurred in a field capable of making industrial world movements whose implications for job competition become non-linear. In addition, this phase of the technological revolution is able to change the way in which human activities take place in scale, scope, complexity, and transformation from previous life experiences. In this era humans are predicted to live in global uncertainty, therefore humans must have

the competence to predict future dynamic conditions. Not only humans, even each country must respond to these changes in an integrated and comprehensive manner. The response was carried out by involving all global political stakeholders, ranging from the public, private sector, academia, to civil society, so that industry challenges 4.0 can be managed into opportunities.

Wolter identified industry challenges 4.0 as follows: (1) information technology security issues; (2) the reliability and stability of the production machine; (3) lack of adequate skills; (4) unwillingness to change by stakeholders; and (5) the loss of a lot of work because it turns into automation (Sung, 2017). Another challenge from Industry 4.0 is; (1) industry readiness; (2) trusted workforce; (3) ease of socio-cultural regulation; and (4) diversification and job creation and 
industry 4.0 opportunities which include ecosystem innovation, competitive industry bases, investment in technology, and integration of Small and Medium Enterprises (SMEs) and entrepreneurship. The world economic forum predicts that the 21 st century skill structure will change. In 2015, the structure of skills is as follows: (1) complex problem solving; (2) collaboration with others; (3) people management; (4) critical thinking; (5) negotiations; (6) quality control; (7) service orientation; (8) assessment and decision making; (9) active listening; and (10); creativity. Whereas in 2020 the work structure changed to: (1) complex problem solving; (2) critical thinking; (3) creativity; (4) people management; (5) cooperation with others; (6) emotional intelligence; (7) assessment and decision making; (8) service orientation; (9) negotiations; and (10) cognitive flexibility.

All forms of skills and skills needed in the 21 st century and industrial era 4.0 must be integrated into all components of education in vocational high schools (SMK). Starting from the learning system, education units, students, to educators and educational staff. In addition, support from the community is needed to improve the good image of vocational schools, so that graduates will feel safe as skilled workers because of the support and recognition from the community. Basically Vocational Schools can be provided or facilitated by the community and government to prepare and change individuals quickly in meeting the demands of the world of work (Murgor, 2013), especially in the balance of facing the industrial phase 4.0 .

\section{Research Method}

This study uses literature review to explain the model of developing student capabilities through industry practices in the 4.0 era in order to improve the quality of vocational education. Conceptual articles are articles that generate new theoretical perspectives, propose new innovative procedures or techniques, discuss warm professional issues, convey the author's position on professional problems, or express reactions or responses to the publication of previous articles. Review literature comes from national and international books and journals. The data collection technique used is documentation. Furthermore, from the documentation in the form of relevant references, the researcher carries out an analysis and comparison with the data. Industrial practice is a productive expertise program. Students must take industrial practices that can be done in the world of work or other agencies, and aim to improve the quality of professionalism of students in a particular job. In addition, industry practice is able to help students gain knowledge about work in accordance with their expertise program. Based on the knowledge gained during industrial practice, the readiness of students to work will be stronger to be practiced when entering the workforce. Industrial practice procedures begin with preparation, implementation and evaluation are shown in Table 1.

Table 1. Industrial Practice Procedures in Vocational Schools

\begin{tabular}{|l|l|}
\hline Sub Focus & Procedure \\
\hline Preparation of industrial practices & $\begin{array}{l}\text { Preparation of industrial practices is carried } \\
\text { out by: 1) providing administrative practices } \\
\text { for industrial students, 2) mapping industry } \\
\text { practices, 3) equipping industry practices; } \\
\text { and 4) the formation of industry practice } \\
\text { mentors. }\end{array}$ \\
\hline
\end{tabular}




\begin{tabular}{|l|l|}
\hline Implementation of industrial practices & $\begin{array}{l}\text { Industry practices are carried out in } \\
\text { accordance with the competencies of their } \\
\text { respective expertise. In some SMKs, } \\
\text { industrial practice is carried out when } \\
\text { students are in grade 11 with a period of } 6 \\
\text { months. }\end{array}$ \\
\hline Evaluation of industry practices & $\begin{array}{l}\text { Evaluation is done after students complete } \\
\text { industrial practices. Evaluation is carried out } \\
\text { in the form of evaluating theory and practice, } \\
\text { one of which is by presenting and collecting } \\
\text { reports }\end{array}$ \\
\hline
\end{tabular}

The implementation of industrial practices begins with preparations starting from providing administrative tools for the implementation of industrial practices for students, mapping industry practices, equipping industrial practices, and forming industrial advisers. Furthermore, in the implementation of industrial practices carried out when students are in class 11 with a period of 6 months. After the students have evaluated, the Vocational School will conduct an evaluation in the form of tests both in theory and practice. So students are required to make presentations and collect reports during industry practice.

\section{Conclusion}

The development of science and technology has brought enormous changes in the world of education. Weak ability of students to develop the capabilities of innovation and creativity will have an impact on the weak competitive advantage and business performance as well. The lack of innovation capability and a good work ethic will have an impact on the backwardness of a country in the economic development and welfare of its people. The problem faced today is the weak capability of human resources, especially in the creativity and capability of innovation. The solution that can be done by vocational education is the presence of industrial practices. The implementation of industrial practices begins with preparations starting from providing administrative tools for the implementation of industrial practices for students, mapping industry practices, equipping industrial practices, forming industrial advisers, implementing industrial practices, and evaluating

\section{Reference}

[1] Baartman, J., dan Bruijin, E. (2011). Integrating Knowlodge, Skills and Attitudes: Conceptualising Learning Processes Vowards Vocational Competence. Educational Research Review. 6 (2): 125-134.

[2] Baur, C. \& Wee, D. (2015). Manufacturing's Next Act.

McKinsey \& Company.

[3] Bukit, M. (2014). Strategi dan Inovasi Pendidikan Kejuruan dari Kompetensi Ke Kompetisi. Bandung: Alfabeta.

[4] Carli, A.L., Suherman, A., dan Sumarna, N. (2016). Studi Keterlaksanaan Proses Pembelajaran Praktik dalam Mencapai Tuntutan Kompetensi Dilihat dari Penggunaan Alat Kerja Praktik Pemeliharaan Mesin Kendaraan Ringan. Journal of Mechanical Engineering Education, 3 (1).

[5] Enke, J., Glass, R., Kreß, A., Hambach, J., Tisch, M., \& Metternich, J. (2018). Industrie 4.0 Competencies for a modern production system. Procedia Manufacturing, 23, 267-272. doi:10.1016/j.promfg.2018.04.028.

[6] Kagermann, H., Wahlster, W., \& Helbig, J. (2013). Recommendations 
for Implementing the Strategic Initiative Industrie 4.0. Industrie 4.0 Working Group, Germany.

[7] Kennedy, O.O. (2011). Philosophical and Sociological Overview of Vocational-Technical Education in Nigeria. Journal of Academic Research In Business And Social Sciences, 1, pp. 167-175.

[8] Kuijpers, M., Meijers, F., \& Gundy, C. (2011). The relationship between learning environment and career competencies of students in vocational education. Journal of Vocational Behavior, 78(1), 21-30. doi:10.1016/j.jvb.2010.05.005.

[9] Lee, J., Lapira, E., Bagheri, B., Kao, H., (2013). Recent Advances and Trends in Predictive Manufacturing Systems in Big Data Environment. Manuf. Lett. 1 (1), pp. 38-41.

[10] Liffler, M., \& Tschiesner, A. (2013). The Internet of Things and the Future of Manufacturing. McKinsey \& Company.

[11] Murgor, T.K. (2013). Relationship Between Technical and Vocational Acquired Skills and Skills Required in Job Market: Evidence from TVET institutions, Uasin Gishu County, Kenya. Journal of Education and Practice, 4 (19), pp. 77-83.

[12] Ndubisi, N. O., Dayan, M., Yeniaras, V., \& Al-hawari Mohammad. (2019). The effects of complementarity of knowledge and capabilities on joint innovation capabilities and service innovation: The role of competitive intensity and demand uncertainty. Industrial Marketing Management. doi:10.1016/j.indmarman.2019.05.0 11.

[13] Oesterreich, T. D., \& Teuteberg, F. (2016). Understanding the implications of digitisation and automation in the context of Industry 4.0: A triangulation approach and elements of a research agenda for the construction industry. Computers in
Industry, $\quad 83, \quad 121-139$. doi:10.1016/j.compind.2016.09.006

[14] Polat, Z., Uzmanoğlu, S., İşgören, N. Ç., Çınar, A., Tektaş, N., Oral, B., Öznaz, D. (2010). Internship education analysis of vocational school students. Procedia - Social and Behavioral Sciences, 2(2), 3452-3456. doi:10.1016/j.sbspro.2010.03.533.

[15] Rossini, M., Costa, F., Staudacher, A. P., \& Tortorella, G. (2019). Industry 4.0 and Lean Production: an empirical study. IFACPapersOnLine, 52(13), 42-47. doi:10.1016/j.ifacol.2019.11.122.

[16] Schaap, H., Baartman, L., \& Bruijn, E. (2012). Students' Learning Processes during School-Based Learning and Workplace Learning in Vocational Education: A Review. Vocations and Learning. 5(2), 99117.

[17] Schwab, K. (2016). The Fourth Industrial Revolution. Switzerland: World Economic Forum.

[18] Sung, T.K. (2017). Industri 4.0: a Korea perspective. Technological Forecasting and Social Change Journal, 1-6.

[19] Tjandrawinata, R. R. (2016). Industri 4.0: Revolusi Industri Abad Ini Dan Pengaruhnya pada Bidang Kesehatan dan Bioteknologi. Jurnal Medicinus, 29 (1).

[20] Trilling, B \& Fadel, C. (2009). 21stCentury Skills: Learning for Life in Our Times. US: Jossey-Bass A Wiley Imprint.

[21] Wibowo, N. (2016). Upaya Memperkecil Kesenjangan Kompetensi Lulusan Sekolah Menengah Kejuruan dengan Tuntutan Dunia Industri. Jurnal Pendidikan Teknologi dan Kejuruan. 23(1), 45.

[22] Zaib, Z., \& Harun, H. (2014). Leadership in Technical and Vocational Education: Toward Excellence Human Capital. Journal 
of Education and Practice, 5 (23), pp. 132-135.

[23] Zesulka, F., Marcon, P., Vesely, I., Sajdl, O. (2016). Industry 4.0 An introduction in the phenomenon. IFAC-Papers Online. 8-12. 